\title{
An Integrated System For Water Resources Monitoring, Economic Evaluation and Management
}

Stratos Arabatzis, Environmental Management Consultant, 30 P. P. Germanou St., 54622 Thessaloniki, Greece, stratos@freemail.gr

Basil Manos, Professor, Department of Agricultural Economics, Aristotle University of Thessaloniki, 54006

Thessaloniki, Greece, manosb@agro.auth.gr

\begin{abstract}
Today an integrated and complete system for the monitoring and management of water resources for a whole river basin does not exist. This paper presents the characteristics and showcases the design of such a system. The core of the system is based on water quality monitoring and risk management. This paper also highlights the need for the economic evaluation of water resources services, and presents a brief description of how these services could be valued. The complete system and methodology can be used for the management of water resources, and can also become the starting point for the design and implementation of more general natural resources management schemes and sustainable development policies.
\end{abstract}

Keywords: water, environment, economics, pollution, monitoring, management.

\section{Introduction}

Today an integrated and complete system for the monitoring and management of water resources for a whole river basin does not exist. Water monitoring activities are fragmented, and, more importantly, very expensive and inefficient (European Commission, 2002, Kristensen et al., 1999). This paper initially presents the characteristics and showcases the design of an integrated and complete system, which we will call WATERMAN. The system can be adapted and used by any interested party, such as public administrations responsible for the management of water resources. On a more general scope, the system can be the starting point for the design and implementation of more general natural resources management schemes and sustainable development policies.

WATERMAN originates from a COPERNICUS pilot project, completed successfully in November 2001 (Manos et al., 1999, Hachikyan et al., 2001). The potential use of the system has recently been investigated through a project funded by the General Secretariat for Research and Technology of the Greek Ministry of Development (PRAXE Project). During this project, a business and exploitation plan was prepared, concerning a company offering environmental consulting and water resource management services. The company was conceived as a spin-off of the Aristotle University of Thessaloniki. The company would possess the knowledge needed for the implementation of an integrated and complete water resource management system and could assist any interested party, such as public administrations responsible for the management of water resources. The following were identified as the company's potential core business areas:

1. Monitoring and management of water resources. The company could coordinate the operation of national and regional resource quality monitoring programs and the provision of chemical and biological (microbiological, hydrobiological and toxicological) analytical services for the assessment of water resources quality. Constant monitoring would provide the information on which a strategic management plan of water resources could be developed.

2. Socio-economic analysis of water resources degradation. The company's services could include the identification and description of the socio-economic effects of water pollution, the economic valuation and monetary estimation of water quality degradation, and the economic evaluation of alternative water resource management and economic development strategies.

In the remaining of this paper we will briefly present the company's modus operandi and then present the science on which the above core business areas are based.

\section{The WATERMAN Company}

The main opportunity for the company is that today an integrated and complete system for monitoring, control, alarming, and management of water resources in a whole river basin does not exist. It is impossible to constantly monitor water quality and balance with today's technology, as this technology is applied at the pollution source level and not at ecosystem level. Monitoring is performed by expensive personnel that visits water resources, 
takes samples, and sends the sample to specialized laboratories, all this at a great cost (Anagnostopoulos, 1985, European Commission, 1995, Nixon et al., 1996, Kristensen et al., 1999). Furthermore, today's technology does not allow the attribution of specific pollution incidents to exact sources, and does not take account of diffuse pollution sources, such as irrigation from agriculture, etc. (Mitrakas, 1996, Arabatzis et al., 2000). Control and alarming are not practiced, and management is whimsical. However, the integrated management of water resources is imminently needed. Therefore a strong demand would be envisaged for the company's services, especially as EC directives are making the integrated management of water resources for a whole river basin an obligation for the responsible authorities (European Commission, 2002). Furthermore, the company could assist the "polluters" to implement clean technologies, and apply environmental and social responsibility principles in their operations.

The company's growth could be significant. The market for water monitoring and management systems is developing rapidly, due to the arising environmental concerns. It is more that certain that today's inadequate water management systems will be supplemented by new systems that provide real time and detailed information on water conditions, enabling successful management. WATERMAN would be in a unique position to provide the technical assistance for the implementation of such a system, and therefore it could target markets both in Greece as well as in the rest of the EU.

The WATERMAN management system would enable the constant analysis of water quality, monitor the sources of pollution, and offer prognoses and recommendations about actions through a decision support system. The application of the system would enhance services to the citizens by improving the quality of water resources, and by ensuring the optimal economic development of their region. The application of WATERMAN can result in the following specific benefits:

- Control of the pollution load discharged to the waters, thus giving nature the chance to regenerate itself.

- Reduction of pollution to a tolerant level for the people and the rest of the ecosystem, thus setting the right standards for the protection of the environment.

- Elimination of hazards for public health through a better management of the underground and ground waters, creating a safe and pleasant environment, increasing quality of life.

On a more general scope, the company would be able to assist governmental and non-governmental organisations on the design and implementation of more general environmental management schemes and sustainable development policies, transferring the methodology and results of water resources management to other resources (air, land, biodiversity, etc.).

\section{Monitoring and Management of Water Resources}

The core of the system is based on water quality monitoring and risk management. The system was named WATERMAN - System for Monitoring and Control of the Situation of Waste Receivers and Automatic Alarming (radio-computer system, GIS, software, satellite observations, installation) (Hachikyan et al., 2001).

The data input in WATERMAN, data processing and evaluation and the decision making follow the process presented in Figure 1. Data come in parallel through 3 channels:

1. From the regional inspectors for environmental protection

2. From an automated radio-computer system

3. From satellite images.

The integration and the complement of the information take place in the RLWM (Bischoff W., R. Scherer, 2002). A great part of the data for the respective indexes are normally doubled. This is useful for validation purposes. Generalized evaluations and hypotheses are formed on the basis of the mathematical models (dynamic systems, stochastics, statistics, optimization, etc.), the software simulation models, and the geographical information system. Knowledge and expert rules are organized as a decision support system (DSS) (Manos et al., 2003, Bournaris et al., 2002). 


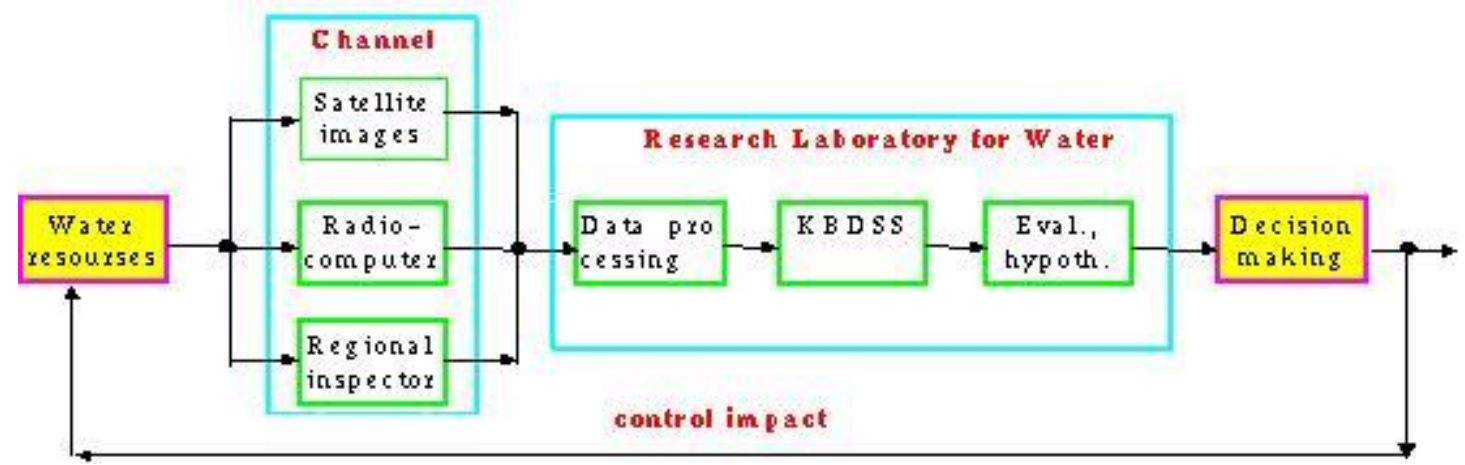

Figure 1. Block Diagram of WATERMAN

In order for such a system to be implemented, the following steps are needed:

1. Development of a radio - computer system for the collection of samples from rivers and underground waters.

2. Definition of the phenomena to be observed

3. Definition of the indexes to be measured and technology of their collection.

For Tasks 1 and 2, first the particular phenomena of the application region have to be selected. These phenomena are of basic importance for the development of a database. The indexes to be measured are received by measurement stations, and by micro-biological analysis (electro conductance, temperature, ammonia, nitrate, nitrite, phosphate, etc.).

Five kinds of indexes are collected:

- Physical and inorganic chemical indexes

- Indexes about organic polluting substances

- Inorganic substances with industrial origin

- Organic substances with industrial origin

- Biological indexes

91 indexes are defined for these 5 groups; 20 of them are regularly measured: water quantity, temperature, dissolved oxygen, $\mathrm{pH}$, electric conductivity, oxidizability, nitrogenous, phosphates, chlorides, sulphates, Fe, Mn, etc. An operator normally takes a part in collecting and sending of the data. Instead of the operator the system uses an automated radio-computer system to collect and send the data. Any imminent pollution incident is traced in its origins and appropriate counter-measures are feasible (Hachikyan et al., 2001, Manos et al., 2003).

\section{Water Quality Variables}

The number of variables describing the quality of a water body have increased and are constantly being modified and further refined along with the expanding uses to which water is put, and also in pace with the development of analytical capabilities to measure more and more substances at ever lower concentrations (Nixon et al., 1996, Kristensen et al., 1999).

The various groups of water users have, to some extent, developed their own approaches and methods to describe and measure water quality. For many decades river basin management and water pollution control have relied on summary variables, such as biochemical oxygen demand (BOD) and chemical oxygen demand (COD) to quantify sewage discharge and oxygen problems in rivers. For the purpose of human consumption and public water supply, a set of microbiological indicator organisms (eg. faecal coliform bacteria) have been identified and their enumeration is now commonly applied to determine the hygienic suitability of water for drinking (Mitrakas, 1996, Kristensen et al., 1999).

The water quality variables can be grouped into the following broad categories (Kristensen et al., 1999):

○ Basic variables (eg. water temperature, $\mathrm{pH}$, conductivity, dissolved oxygen, and discharge) used for a general characterization of water quality. 
○ Suspended particulate matter (eg. suspended solids, turbidity and organic matter (TOC, BOD and COD)).

○ Organic pollution indicators (eg. dissolved oxygen, Biochemical Oxygen Demand (BOD), Chemical Oxygen Demand (COD), ammonium).

$\circ$ Indicators of eutrophication: nutrients (eg. nitrogen and phosphorus), and various biological effect variables (eg. chlorophyll a, Secchi disc transparency, phytoplankton, zoobenthos).

- Indicators of acidification (eg. pH, alkalinity, conductivity, sulphate, nitrate, aluminium, phytoplankton and diatom sampling)

- Specific major ions (eg. chloride, sulphate, sodium, potassium, calcium and magnesium) as essential factors in determining the suitability of water for most uses (eg. public water supply, livestock watering and crop irrigation)

- Metals (eg. cadmium, mercury, copper and zinc)

- Organic micropollutants such as pesticides and the numerous chemical substances used in industrial processes (eg. PCB, HCH, PAH).

- Indicators of radioactivity (eg. total alpha and beta activity, 137Cs, 90Sr)

- Microbiological indicator organism (eg. total coliforms, faecal coliforms and faecal streptococci bacteria)

- Biological indicators of the environmental state of the ecosystem (eg. phytoplankton, zooplankton, zoobenthos, fish, macrophytes and birds and animals related to surface waters).

Below we present a more detailed reference table of water quality variables, adapted from Kristensen et al. (1999).

Table 1: Water quality variables

\begin{tabular}{|c|c|c|c|}
\hline Basic variables & \begin{tabular}{|l|l|}
$\begin{array}{l}\text { Suspended particulate } \\
\text { matter }\end{array}$ \\
\end{tabular} & $\begin{array}{l}\text { Organic pollution } \\
\text { indicators }\end{array}$ & \begin{tabular}{|l|} 
Eutrophication - \\
nutrients
\end{tabular} \\
\hline $\begin{array}{l}\text { water flow (Q) } \\
\text { water temperature } \\
\text { (TEMPW) } \\
\text { pH (PH) } \\
\text { conductivity } \\
\text { (COND) } \\
\text { dissolved oxygen } \\
\text { (OX) } \\
\text { colour (CNR) } \\
\text { turbidity (TURB) }\end{array}$ & $\begin{array}{l}\text { suspended matter (SM) } \\
\text { turbidity (TURB) } \\
\text { Biological Oxygen De- } \\
\text { mand (BOD) } \\
\text { Chemical Oxygen Demand } \\
\text { (COD) } \\
\text { Total Organic Carbon } \\
\text { (TOC) }\end{array}$ & $\begin{array}{l}\text { dissolved oxygen (OX) } \\
\text { Biological Oxygen De- } \\
\text { mand (BOD) } \\
\text { Chemical Oxygen Demand } \\
\text { (COD) } \\
\text { Total Organic Carbon } \\
\text { (TOC) } \\
\text { ammoniacal nitrogen } \\
(\mathrm{NH} 4 \mathrm{~N})\end{array}$ & $\begin{array}{l}\text { total phosphorus (PTOT); } \\
\text { dissolved reactive phosphate } \\
\text { (PO4P) } \\
\text { total or Kjeldahl nitrogen } \\
\text { (NTOT) } \\
\text { oxidized nitrogen (NO23N) } \\
\text { nitrite nitrogen (NO2N); } \\
\text { ammoniacal nitrogen } \\
\text { (NH4N) } \\
\text { chlorophyll a (CHLA) } \\
\text { Secchi disc transparency } \\
\text { (SDT) }\end{array}$ \\
\hline Major specifications & Metals & Indicators of acidification & Organic micropollutants \\
\hline $\begin{array}{l}\text { chloride (CL) } \\
\text { sulphate (SO4) } \\
\text { bicarbonate (HCO3) } \\
\text { carbonate (CO3) } \\
\text { sodium (NA) } \\
\text { potassium (K) } \\
\text { calcium }(\mathrm{CA}) \\
\text { magnesium (MG) } \\
\text { silica (SIO2) } \\
\text { arsenic (AS) } \\
\text { cyanide (CN) }\end{array}$ & $\begin{array}{l}\text { aluminium }(\mathrm{AL}) \\
\text { cadmium }(\mathrm{CD}) \\
\text { chromium }(\mathrm{CR}) \\
\text { copper }(\mathrm{CU}) \\
\text { iron }(\mathrm{FE}) \\
\text { mercury }(\mathrm{HG}) \\
\text { manganese }(\mathrm{MN}) \\
\text { nickel }(\mathrm{NI}) \\
\text { lead }(\mathrm{PB}) \\
\text { zinc }(\mathrm{ZN})\end{array}$ & $\begin{array}{l}\mathrm{pH}(\mathrm{PH}) \\
\text { alkalinity (ALK) } \\
\text { conductivity (COND) } \\
\text { Total Organic Carbon } \\
\text { (TOC) } \\
\text { nitrate (NO3N) } \\
\text { the } 4 \text { major cations (CA, K, } \\
\mathrm{MG}, \mathrm{NA} \text { ) \& the anions } \\
\text { (CL, SO4) } \\
\text { aluminium fractions (AL- } \\
\text { frac.) }\end{array}$ & $\begin{array}{l}\text { solvents } \\
\text { PAH } \\
\text { PCB } \\
\text { chlorophenols } \\
\text { organo-Cl-pesticides } \\
\text { gamma-HCH } \\
\text { DDT } \\
\text { hexachlorobenzene } \\
\text { halogenated aromatics } \\
\text { phenol compounds } \\
\text { DDE } \\
\text { anionic detergents } \\
\text { alpha-HCH } \\
\text { DDD } \\
\text { dieldrin } \\
\text { atrazin } \\
\text { benzo(a)pyrene } \\
\text { extractable organic halogens } \\
\text { oil } \\
\text { pentachlorophenol } \\
\text { trichloromethane }\end{array}$ \\
\hline
\end{tabular}




\begin{tabular}{||l|l|l|l||}
\hline Radionuclides & $\begin{array}{l}\text { Microbiological indica- } \\
\text { tors }\end{array}$ & Biological indicators & \\
\hline Total alpha activity & total coliform bacteria & macroinvertebrates & \\
(COLITOT); & (INVERT) & \\
& faecal coliform bacteria & zoobenthos (INVERT) \\
phytobenthos (PHYTBEN) & (COLIFAEC); & faecal streptococci bacteria & phytoplankton (PHYTPL) \\
& zooplankton (ZOOPL) & \\
& (STR_FAEC) & Salmonella (SALMONEL) & macrophytes (MPHYT) \\
fish (FISH) & \\
\hline
\end{tabular}

Integration with GIS

For WATERMAN to operate effectively, geographic information is needed. This information concerns sources of pollution, existing watersheds, transport networks, and exposed populations. A Geographic Information System (GIS) is the right tool for supplying this information, so GIS capability is developed. The combined display of major water pollution sources (industries, population centers) and readings from water monitoring stations provide a systematic basis for addressing critical water pollution problems (Gotchev et al., 2000, Wheeler, 1997).

Once the GIS is integrated with all environmental information in the Decision Support System, WATERMAN moves to a new level of monitoring and enforcement capability. For example, the GIS provides 'point-click' access to information on any data source which is identified on the geographic display. A map presents all emissions sources in an area, indicated by a particular symbol. A click on one of these symbols brings up a data file on that source: its emissions, facility characteristics (e.g., sector, employment, output, use of raw materials, energy use, etc.); inspection data; outstanding complaints; and enforcement actions. Equipped with this kind of information, public officials are in a much better position to target their monitoring and enforcement resources.

\section{Socio-economic Analysis of Water Resources Degradation}

The purpose of socio-economic analysis is to study the socio-economic impacts and assign a monetary figure to the environmental degradation of a region. This will enable direct comparisons between the damages that are the result of pollution and the costs of corrective measures. If the incurred damages are higher than the cost of corrective measures, then the application of such measures is justified (Arabatzis et al., 2000).

The need for socio-economic analysis stems from the recognition that all human activity relies on the natural environment (Kapp, 1975). Environmental resources such as rivers, lakes, land, air, or even living organisms, are subject to different and often competing uses by people. Environmental resources sustain the ecological processes on which life depends, but they also provide inputs to the production of goods and services, and act as sinks for waste and pollution. They have uses which are not obvious or which we do not fully understand.

Environmental resources also have value beyond their direct use. For example, some resources are important for cultural, religious or scientific reasons. There is a widely held view that humans should act as stewards of the planet's resources, serving the interests of future generations. Another argument proposes that the natural environment has inherent value, independent of human use (Tietenberg, 2002).

For these reasons, there is a need for the management of the natural environment in ways to ensure its survival and best use over time. The "sustainable development" principle has emerged to meet this need (Randall, 1987, Kyriakou, 1995). Economic evaluation greatly assists the optimal and sustainable development of an area. Economic evaluation also enables the application of the polluter pays principle. The principle's goal is that the polluter pays the full cost of the pollution it causes (OECD, 1992). In a broader sense, the principle's goal is that every human activity has to pay its full cost. This means that not only labour, capital, land, and raw materials should be accounted for, but also the cost to the society from the degradation to the environment, caused by the side-products (waste) of the human activity.

The principle does not intent to punish the polluter, but to establish the necessary economic conditions so that all the environmental costs associated with the operation of a polluter are fully accounted and paid, so that the cost of production equals the real cost of produced goods, leading to sustainable development. As it is evident, the principle aims at stopping the waste of natural resources and the cost-free use of the environment for waste disposal. The correct and full implementation of the principle leads to the more efficient and fair operation of the 
market, and eliminates conditions of unfair competition that might be present when the industry does not pay the full environmental cost of its operation (Arabatzis et al., 2000).

\section{The Role of Monetary Valuation}

Many environmental resources are not traded in markets and so do not have an obvious price. There is a danger, therefore, that the effects of human activity on the natural environment will be ignored. If they are not fully taken into consideration there is a danger that the decisions made will not be in the best interest of society (Sen, 1982, Randall, 1987).

Though environmental effects do not have a price, this does not mean they do not have value. This is the difference between financial analysis-which is concerned only with goods and services traded in markets-and economic analysis-which is concerned with society's well-being or welfare. If we are concerned with people's welfare, we must fully consider environmental effects.

In recent years, progress has been made in defining environmental values and effects (EPA, 1995, Islam et al., 2003), in techniques for estimating their monetary values and in defining the role of valuation in policy formulation (EPA, 2000). Economists measure environmental values in terms of an individual's willingness to pay or accept compensation (Binning et al., 1995, Tietenberg, 2002). For environmental amenities to have economic value, a person must be willing to pay an amount of money to obtain the amenity or willing to accept an amount of money as compensation for its loss.

Monetary values are readily observable for commodities regularly exchanged in the market place. However, because many environmental resources such as clean air, wilderness, the existence of wildlife and scenic vistas are not exchanged in markets they are unpriced. Nonetheless, these non-market resources have monetary value as long as people are willing to trade some of their income and wealth for them. In this way monetary values do not depend upon whether people actually trade money for the benefits received.

\section{The Concept of Economic Value}

The total economic value of environmental amenities comprises explicit use benefits as well as implicit non-use benefits (Binning et al., 1995, Tietenberg, 2002). Use benefits are those that accrue from the physical use of environmental resources such as visiting a wilderness area or recreational fishing.

The benefits from productive activities such as agriculture, forestry or fisheries are also included in this category. Use benefits also comprise benefits unaccompanied by market exchanges or explicit activities. For example, people may derive use benefits simply from experiencing a place without actually participating in any explicit activities.

Non-use benefits, on the other hand, refer to the benefits individuals may obtain from environmental resources without directly using or visiting them. An individual-either a user or a nonuser-might be willing to pay something to maintain a high level of water quality at a recreation site in a particular area, even though he will not use it, so that her children may have future use of the site, or simply to know that the ecosystem at the site will be maintained.

They are classified into five types (Binning et al., 1995):

1. Existence value: the welfare obtained from the knowledge that an environmental resource exists. The concept may also include the benefits obtained from knowing that culturally important resources are protected.

2. Vicarious value: the welfare obtained from the indirect consumption of an environmental resource through books and other media.

3. Option value: the welfare obtained by retaining the option to use an environmental resource at some future date. Option value stems from the combination of the individual's uncertainty about future demand for the resource and uncertainty about its future availability. Relevant to both current users and potential future users, option value is the amount an individual would be willing to pay for improved environmental resource quality (over his expected user values) to have the right to use the resource in the future when there is uncertainty either in the resource's availability at a particular quality level or in his use of it (with the resource meeting specified quality conditions). For example, if an individual might use a river, but is not sure he will, he may pay some amount each year for the right (or option) to use it (with the river meeting 
specified water quality conditions). Under some conditions, this payment, the option price, will exceed his expected consumer surplus - the value he would derive from anticipated use. This excess - the amount that the option price exceeds the expected consumer surplus - is defined as the option value.

4. Quasi-option value: the welfare obtained from the opportunity to get better information by delaying a decision that may result in irreversible environmental loss. This kind of value may be obtained when future technologies or knowledge enhance the value of a natural resource.

5. Bequest value: the welfare that the current generation obtains from preserving the environment for future generations.

Each of these non-use benefits can increase welfare and so each must be recognised in any analysis.

The concept of economic value can therefore be summarised as follows:

Economic value $=$ use values + non-use values

Non-use values $=$ existence value + vicarious value + option value + quasi-option value + bequest value

\section{Estimating Monetary Values}

The monetary valuation of the socioeconomic effects is feasible with the use of some or all of the following methods (Sinded, 1990, Walpole, 1991, Binning et al., 1995, EPA 2000, Tietenberg, 2002):

Table 2. Monetary valuation methods.

\begin{tabular}{|l|l|l|}
\hline Market based & $\begin{array}{l}\text { Based on adjacent/corollary } \\
\text { markets }\end{array}$ & Based on shadow market analysis \\
\hline $\begin{array}{l}\text { - Market Price/Demand Function } \\
\text { - Supply or Cost Function }\end{array}$ & $\begin{array}{l}\text { - Property value } \\
\text { - Hedonic Price/Wage- } \\
\text { - Consumer/Producer Cost Savings } \\
\text { - Change-in-productivity }\end{array}$ & $\bullet$ Contingent valuation (WTP, \\
- Change-in-income & - Proxy-good & $\bullet$ Trade-off game \\
- Replacement cost & Travel Cost Method & $\begin{array}{l}\text { Contingent ranking and } \\
\text { contingent rating }\end{array}$ \\
- Preventative Expenditure & & $\bullet$ The priority-evaluator technique \\
- Relocation Cost & & $\bullet$ Averting Behavior \\
\hline
\end{tabular}

\section{Estimating Monetary Values for Water Resources}

The estimation of monetary values for water resources presupposes the identification and evaluation of the uses of water, as provided services. Below we provide a detailed list of water services, adapted from EPA (1995), first for ground water, and then for surface water. The valuation techniques mentioned above can be used selectively to estimate the value of each service.

Table 3. Ground water services. Ground water stored in an aquifer provides a reserve (stock) of water which can be directly used to generate services. Potential service flows and effects of these services are listed below.

\begin{tabular}{|c|c|c|}
\hline & SERVICES & EFFECTS \\
\hline 1 & Provision of drinking water & $\begin{array}{l}\text { - Change in welfare from increase or decrease in } \\
\text { availability of drinking water } \\
\text { - Change in human health or health risks }\end{array}$ \\
\hline 2 & Provision of water for crop irrigation & $\begin{array}{l}\text { - Change in value of crops or production costs } \\
\text { - Change in human health or health risks }\end{array}$ \\
\hline 3 & Provision of water for livestock & $\begin{array}{l}\text { - Change in value of livestock products or production } \\
\text { costs } \\
\text { - Change in human health or health risks }\end{array}$ \\
\hline 4 & $\begin{array}{l}\text { Provision of water for food product } \\
\text { processing }\end{array}$ & $\begin{array}{l}\text { - Change in value of food products or production costs } \\
\text { - Change in human health or health risks }\end{array}$ \\
\hline 5 & $\begin{array}{l}\text { Provision of water for other manufacturing } \\
\text { processes }\end{array}$ & $\begin{array}{l}\text { - Change in value of manufactured goods or production } \\
\text { costs }\end{array}$ \\
\hline 6 & $\begin{array}{l}\text { Provision of heated water for geothermal } \\
\text { power plants }\end{array}$ & - Change in cost of electricity generation \\
\hline 7 & Provision of cooling water for other power & - Change in cost of electricity generation \\
\hline
\end{tabular}




\begin{tabular}{|c|c|c|}
\hline & plants & \\
\hline 8 & $\begin{array}{l}\text { Provision water/soil support system for } \\
\text { preventing land subsidence market }\end{array}$ & - Change in cost of maintaining public or private property \\
\hline 9 & $\begin{array}{l}\text { Provision of erosion and flood control } \\
\text { through absorption of water run-off }\end{array}$ & - Change in cost of maintaining public or private property \\
\hline 10 & $\begin{array}{l}\text { Provision of medium for wastes and other } \\
\text { by-products of human economic activity }\end{array}$ & $\begin{array}{l}\text { - Change in human health or health risks attributable to } \\
\text { change in ground water quality } \\
\text { - Change in animal health or health risks attributable to } \\
\text { change in ground water quality } \\
\text { - Change in economic output attributable to use of ground } \\
\text { water resource as "sink" for wastes }\end{array}$ \\
\hline 11 & $\begin{array}{l}\text { Provision of clean water through support of } \\
\text { living organisms }\end{array}$ & $\begin{array}{l}\text { - Change in human health or health risks attributable to } \\
\text { change in water quality } \\
\text { - Change in animal health or health risks attributable to } \\
\text { change in water quality } \\
\text { - Change in value of economic output or productions } \\
\text { attributable to change in water quality }\end{array}$ \\
\hline 12 & $\begin{array}{l}\text { Provision of passive or non-use services } \\
\text { (e.g., existence or bequest motivations) }\end{array}$ & - Change in personal utility \\
\hline
\end{tabular}

Table 4. Surface Water uses/services. Surface water in streams, lakes, and wetlands offers an array of services, whose effects are listed below.

\begin{tabular}{|c|c|c|}
\hline & SERVICES & EFFECTS \\
\hline 1 & Provision of drinking water & $\begin{array}{l}\text { - Change in welfare from increase or decrease in } \\
\text { availability of drinking water (access value) } \\
\text { - Change in human health or health risks }\end{array}$ \\
\hline 2 & Provision of water for crop irrigation & $\begin{array}{l}\text { - Change in value of crops or production costs } \\
\text { - Change in human health or health risks }\end{array}$ \\
\hline 3 & Provision of water for livestock & $\begin{array}{l}\text { - Change in value of livestock products or production } \\
\text { costs } \\
\text { - Change in human health or health risks }\end{array}$ \\
\hline 4 & $\begin{array}{l}\text { Provision of water for food product } \\
\text { processing }\end{array}$ & $\begin{array}{l}\text { - Change in value of food products or production costs } \\
\text { - Change in human health or health risks }\end{array}$ \\
\hline 5 & $\begin{array}{l}\text { Provision of water for other manufacturing } \\
\text { processes }\end{array}$ & $\begin{array}{l}\text { - Change in value of manufactured } \\
\text { - Goods or production costs }\end{array}$ \\
\hline 6 & $\begin{array}{l}\text { Provision of cooling water for power } \\
\text { plants }\end{array}$ & - Change in cost of electricity generation \\
\hline 7 & $\begin{array}{l}\text { Provision of erosion, flood, and storm } \\
\text { protection }\end{array}$ & $\begin{array}{l}\text { - Change in cost of maintaining public or private property } \\
\text { - Change in human health or health risks through personal } \\
\text { injury protection } \\
\text { - Change in economic output attributable to use of surface } \\
\text { water supplies for disposing wastes }\end{array}$ \\
\hline 8 & $\begin{array}{l}\text { Transport and treatment of wastes and } \\
\text { other by-products of human economic } \\
\text { activity }\end{array}$ & $\begin{array}{l}\text { - Change in human health or health risks attributable to } \\
\text { change in surface water quality } \\
\text { - Change in animal health or health risks attributable to } \\
\text { change in surface water quality } \\
\text { - Change in economic output attributable to use of surface } \\
\text { water supplies for disposing wastes }\end{array}$ \\
\hline 9 & $\begin{array}{l}\text { Support of recreational swimming, } \\
\text { boating, fishing, hunting, trapping and } \\
\text { plant gathering }\end{array}$ & $\begin{array}{l}\text { - Change in quantity or quality recreational activities } \\
\text { - Change in human health or health risks }\end{array}$ \\
\hline 10 & $\begin{array}{l}\text { Support of commercial fishing, hunting, } \\
\text { trapping, plant gathering }\end{array}$ & - Change in value of commercial harvest or costs \\
\hline 11 & $\begin{array}{l}\text { Support of on-site observation or study of } \\
\text { fish, wildlife, and plants for leisure, } \\
\text { educational, or scientific purposes }\end{array}$ & $\begin{array}{l}\text { - Change in quantity or quality of on- site observation or } \\
\text { study activities }\end{array}$ \\
\hline 12 & $\begin{array}{l}\text { Support of indirect, off-site fish, wildlife, } \\
\text { and plant uses (e.g. viewing wildlife }\end{array}$ & $\begin{array}{l}\text { - Change in quantity or quality of indirect, off-site } \\
\text { activities }\end{array}$ \\
\hline
\end{tabular}




\begin{tabular}{|c|c|c|}
\hline & photos) & \\
\hline 13 & $\begin{array}{l}\text { Provision of clean air through support of } \\
\text { living organisms }\end{array}$ & $\begin{array}{l}\text { - Change in human health or health risks attributable to } \\
\text { change in air quality } \\
\text { - Change in animal health or health risks attributable to } \\
\text { change in air quality }\end{array}$ \\
\hline 14 & $\begin{array}{l}\text { Provision of clean water through support } \\
\text { of living organisms }\end{array}$ & $\begin{array}{l}\text { - Change in human health or health risks attributable to } \\
\text { change in water quality } \\
\text { - Change in animal health or health risks attributable to } \\
\text { change in water quality } \\
\text { - Change in value of economic output or productions costs } \\
\text { attributable to change in water quality }\end{array}$ \\
\hline 15 & $\begin{array}{l}\text { Regulation of climate through support of } \\
\text { plants }\end{array}$ & $\begin{array}{l}\text { - Change in human health or health risks attributable to } \\
\text { change in climate } \\
\text { - Change in animal health or health risks attributable to } \\
\text { change in climate } \\
\text { - Change in value of economic output or production costs } \\
\text { attributable to change in climate }\end{array}$ \\
\hline 16 & $\begin{array}{l}\text { Provision of non-use services associated } \\
\text { with surface water or wetlands or } \\
\text { ecosystems }\end{array}$ & - Change in personal utility or satisfaction \\
\hline
\end{tabular}

\section{Bibliography}

- Anagnostopoulos, A. (1985). Environmental pollution, $1^{\text {st }}$ edition by the author, Thessaloniki.

- Arabatzis E., H. Papadopoulou, B. Manos and A. Papadopoulos (2000). The implementation of the Pollution Pays principle in the fruit and vegetable canning industry in Greece», Proceedings of Fifth International Conference on Environmenatl Pollution, Thessaloniki.

- Binning Carl, Marc Carter, Kathleen Mackie, Nicole Matthews, Gene McGlynn, Peter McVay, David Palmer, Michelle Scoccimarro, Leanne Wilks, Jack Sinden, David James (1995). "A handbook of environmental evaluation", the Commonwealth Department of the Environment, Sport and Territories, the Commonwealth Department of Finance, and the Resource Assessment Commission, Australian Government Publishing Service, Canberra.

- Bischoff W., R. Scherer (2002). Mathematical Modelling for the Waterman project, Proceedings of 6th Balkan Conference on Operational Research, Thessaloniki, Greece.

- Bournaris Th., B. Manos, N. Silleos, V. Antonopoulos. (2002). A decision support system approach for monitoring and sustainable management of Strymon river, Proceedings of 1st Conference of Hellenic Association of Information and Communication Technology in Agriculture, Food and Environment, Athens.

- EPA (1995). A Framework for Measuring the Economic Benefits of Ground Water, Boyle, Kevin J., Bergstrom, John C.

- EPA (2000). Guidelines for Preparing Economic Analyses.

- European Commission (1995). Waste Water Charge Schemes in the European Union (updated regularly at the European Commission's web site - http://europa.eu.int)

- European Commission (2002). Decision No 1600/2002/EC of the European Parliament and of the Council of 22 July 2002 laying down the Sixth Community Environment Action Programme, OJ L 242, 10/9/2002.y

- Gotchev G., R. Scherer, M. Lazarova, A. Hachikyan (2000). Structural-Linguistic Presentation of a River System in GIS, Proceedings of Technical University of Sofia.

- Hachikyan A., R. Scherer, D. Bojchev, G. Gotchev (2001). Expert System for Water Management, Application of Mathematics in Engineering and Economics, Heron Press, Sofia.

- Islam S. M. F., H. Papadopoulou, B. Manos (2003). Ecological sustainability in Greek agriculture: An application of energy flow approach, Journal of Environmental Planning and Management, volume 46, No 6.

- Kapp, William K. (1975, $1^{\text {st }}$ edition 1952). The Social Costs of Private Enterprise.

- Kristensen Peter, Jens Bøgestrand, N. Thyssen (1999). Surface water quality monitoring. Topic report No 2/1996, National Environmental Research Institute, Denmark, and European Environment Agency, Denmark.

- Kyriakou, Dimitrios (1995). Sustainable development: Towards a synthesis. Institute for prospective technological studies, Seville, Spain.

- Manos B., Th. Bournaris, N. Silleos, V. Antonopoulos, J. Papathanasiou (2003). A decision support system approach for rivers monitoring and sustainable management, Environmental Monitoring and Assessment, 00:1-14. 
- Manos B., N. Silleos and B. Antonopoulos (1999). Development of an automatic system for quantitative and qualitative data acquisition and modeling of transborder rivers by using GIS and mathematical models, Proceedings of 1st Special Conference of Hellenic Operational Research Society, Development of Primary Sector in 21st Century, Ioannina.

- Mitrakas, M. (1996). Qualitative characteristics and water treatment, Thessaloniki.

- Nixon S. C., Y. J. Rees, J. A. Gunby and T. J. Lack (1996). European freshwater monitoring, summary of network design, European Topic Centre on Inland Waters, European Environment Agency, Copenhagen.

- OECD (1992). The polluter pays principle.

- OECD (2002). Handbook of biodiversity valuation: A guide for policy makers.

- Randall, Alan (1987). Resource Economics: An Economic Approach to Natural Resource and Environmental Policy.

- Sen, Amartya (1982). Choice, Welfare and Measurement.

- Sinden, J.A. (1990) Valuation of Unpriced Benefits and Costs of River Management, Office of Water Resources, Victorian Department of Conservation and Environment, Melbourne.

- Tietenberg, Tom (2002). Environmental and Natural Resource Economics, sixth edition, Pearson Addison Wesley, USA.

- Walpole Sandra (1991) 'The Recreational and Environmental Benefits of the Ovens-King River Systems', Australian Parks and Recreation, vol. 27, no.4, pp.33-37.

- Wheeler, David (1997). Information in pollution management: The new model, from "Brazil: Managing Pollution Problems, The Brown Environmental Agenda", Report 16513-BR, The World Bank. 